\title{
SAPONINS AND SAPOGENINS OF AGAVE WITH RESPECT TO DIVERSE PHARMACOLOGICAL ROLE OF HECOGENIN
}

\author{
DEEPA K. INGAWALE (MANDLIK)
}

Bharati Vidyapeeth University (Deemed to be University), Poona College of Pharmacy, Erandawane, Pune 411038, Maharashtra, India Email: deepa_ingawale@yahoo.com

Received: 20 Sep 2019, Revised and Accepted: 25 Dec 2019

ABSTRACT

The review outlines the current understandings of saponins and sapogenins in agave species with special focus on pharmacological role of hecogenin in numerous preclinical studies. A systematic literature survey was done on the pharmacological activities of hecogenin during the past $40 \mathrm{y}$ with electronic databases like PubMed, Science Direct, Wiley, SciFinder, Google Scholar, Web of Science and Scopus. Hecogenin, a steroidal sapogenin found abundantly in the leaves of Agave genus species such as, Agave sisalana, Agave cantala, Agave aurea and many more. This phytosteroid (hecogenin) is used as initial material for the synthesis of steroidal drugs in the pharmaceutical industry. Hecogenin has exhibited potential role in the management of a number of disorders such as inflammation, arthritis, cancer, gastric ulcer, cardiotonic and larvicidal activity. In this review, we have summarized the saponins and sapogenins present in the Agave species and pharmacological roles of hecogenin with their mechanism of action.

Keywords: Agave genus, Saponin, Sapogenin, Hecogenin, Pharmacological activities

(C) 2020 The Authors. Published by Innovare Academic Sciences Pvt Ltd. This is an open access article under the CC BY license (http://creativecommons.org/licenses/by/4.0/) DOI: http://dx.doi.org/10.22159/ijpps.2020v12i2.35789. Journal homepage: https://innovareacademics.in/journals/index.php/ijpps

\section{INTRODUCTION}

The genus Agave contains above 400 species growing in dry and semi-dry environments belongs to the family Agavaceae (fig. 1). These plants are often called as 'wild century', 'hardy century,' or 'rough century' plants as they are growing in dry lands. The plant is also known as 'century plant' indicates a huge application of Agave plant [1]. Beverages, fiber and food materials have been obtained from the agave plants [2]. In the recent times, Agave species have also been used as a nutraceutical, natural sweeteners, prebiotics, biofuels and source of steroidal sapogenins [3]. The research work on Agave saponins was initially presented by Jones et al. in 1932 [4] Moreover, Agave was considered as a novel and budding source of sapogenins [5]. Up till now, not less than 50 species of Agave plants have been discovered for their sapogenin and saponin phytoconstituents. The previous review work has furnished a phytochemistry summary of the family belonging to Agavaceae [6]. It comprised of several saponins and sapogenins of Agave such as Dracaena, Yucca, Cordyline, Nolina, Furcraea and Sansevieria. The other review entitled traditional products of Agave species has presented information about Agave food, nutraceutical and pharmacological properties of extracts [7]
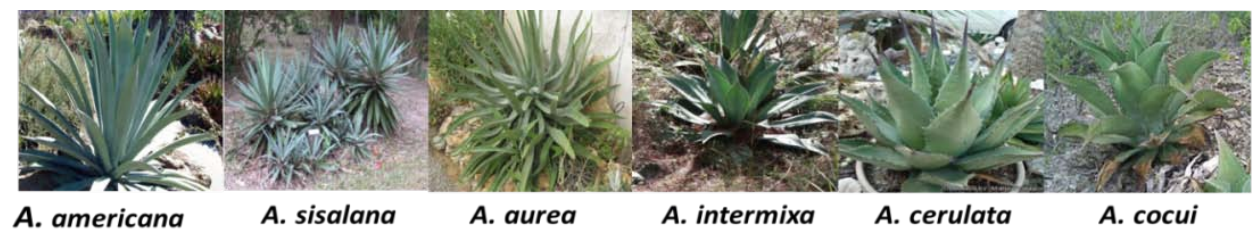

A. sisalano

A. aurea

A. intermixa

A. cerulata

A. cocui
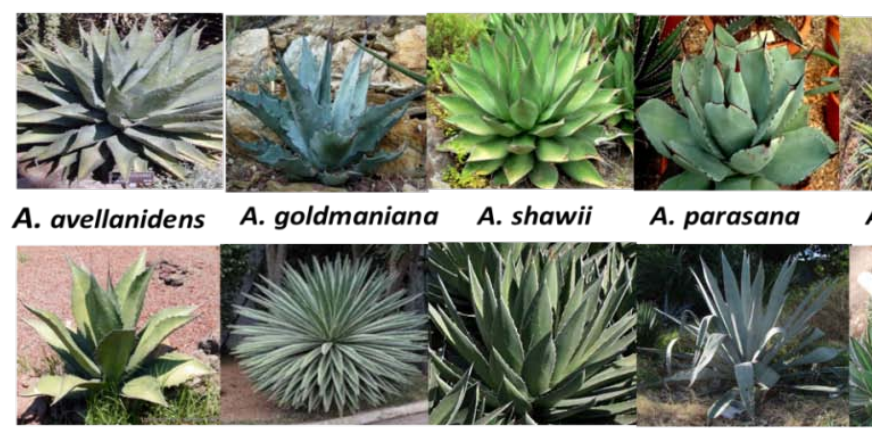

A. goldmaniana

A. shawii

A. parasana

A. utahensis

A. canatala

A. ferox

A. variegata

A. ghiesbrechtii

A. vera-cruz

A. Iophantha

A. haynaldii
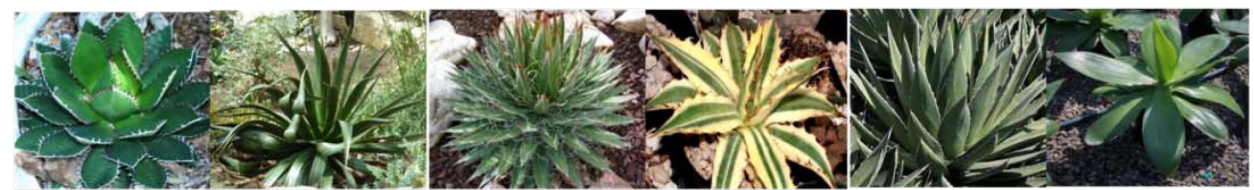

A. horride

A. toneliana

A. filifera

A. rigidissima A. ghiesbrechtii

A. ellemeetiana

Fig. 1: Different species of Agave genus 
Saponins are the glycosides of steroids or triterpenes with numeral of pharmacological activities like anti-oxidant, immuno-stimulant, anti-inflammatory, anti-cancer, adjuvant, anti-microbial, hypocholesterolemic properties [8]. In current days, biologists and chemists are focusing their attention on saponins for the purpose of new drug discovery $[9,10]$. The applicability of these steroidal compounds has been increasing for therapeutic purpose along with principal component in the drug discovery methodologies [11].

Over the years, the interest of many researchers has been increasing due to industrial applicability of steroidal sapogenins. In addition to this, hecogenin exhibits variety of important biological activities in the pharmaceutical industry $[12,13]$. The steroidal sapogenins (hecogenin) from Agave genus were reported to have a number of pharmacological activities such as anti-inflammatory, analgesic, antiarthritis, gastroprotective, anticancer and larvicidal activity [14-18]. Overall, the results of numerous pharmacological studies have been linking the possible use of hecogenin as a novel multi-target based therapeutic agent against abundant long-lasting disease conditions. The present review emphasizes on steroidal saponins and sapogenins of Agave genus with numerous pharmacological activities with respect to their mechanism of action.

\section{Saponins and sapogenins from agave genus}

Different Agave species has been reported for various primary and secondary metabolites. Carbohydrates [3], Agave syrups as a functional foods, natural sweeteners, prebiotics [2] are the examples of primary metabolites from Agave whereas, the examples of secondary metabolites includes sterols, steroidal saponins and sapogenins [19], flavonoids [20], homoisoflavonoids [21], tannins [20], phenolic acids [22], volatile coumarins [20], long chain alkanes, fatty acids and alcohols [21,23]. Steroidal saponins and sapogenins are the most commonly studied compounds in Agave genus.

\section{Sapogenins}

Two different steroidal sapogenins are identified from the Agave such as spirostanol-type (1-27) and cholestane-type (Agavegenin D-28). Up till now, sapogenins of furostanol and furospirostanol skeleton have not been discovered in Agave genus. 16, 22; 22, 26bisepoxycholestanes gives rise to spirostanols sapogenins. The spirostanol skeleton made up of a tetrahydrofuran ring and a tetrahydropyran ring attached to $\mathrm{C}-22$ position in a spiran fashion. Spirostanols sapogenins are isolated from the callus cultures, flowers, leaves, leaf juice, rhizomes of Agave plants. Spirostanol sapogenins of Agave differ from each other in terms of a) presence or absence of carbonyl group at $\mathrm{C}-12, \mathrm{~b}$ ) configuration and number of the hydroxyl moieties attached to the parent nucleus, c) presence or absence of unsaturation in rings $\mathrm{B}$ or $\mathrm{C}$ and d) configuration of $\mathrm{H}$ at C-5 and C-25.

\section{Saponins}

A hydrophobic aglycone (sapogenin) unit and a hydrophilic sugar (glycone) unit combines together to form a saponin molecule. The sugar moieties of Agave saponins include $\beta$-D-glucopyranosyl, $\beta$-Dxylopyranosyl, $\beta$-D-galactopyranosyl and $\alpha$-L-rhamnopyranosyls. The saponins of Agave are classified into two types such as spirostanol and furostanol glycosides, depending on the basis of sapogenin nucleus present in it. These compounds are further classified into monoglycosides, diglycosides, triglycosides, tetraglycosides, pentaglycosides or hexaglycosides on the basis of number of sugars moieties attached to it. If the sugar chain is present at only one position of the sapogenin, it is called as monodesmosidic. Bidesmosidic saponins contains, two sugar units located at two different points of sapogenin [24]. The spirostanol saponins of Agave are monodesmosidic and have sugar unit attached at the C-3 position of aglycone moiety. Bidesmosidic spirostanol saponins are relatively very rare in Agave plants.

\section{Reported pharmacological roles of hecogenin}

Hecogenin is a steroidal sapogenin (fig. 2) isolated from the leaves of Agave genus species such as Agave cantala, Agave sisalana, Agave aurea and many more [25]. The cultivation of hecogenin is extensively spread throughout the tropical and subtropical regions [26]. Brazil represents one of the largest producers (69\%) of hecogenin [27].
Hecogenin was reported as an important therapeutic agent due to its valuable pharmacological properties involving antioxidant, antiinflammatory, antifungal, hypotensive, anti-nociceptive [28], larvicidal, cardioactive, anti-proliferative activity in human osteosarcoma cells [29] and anti-hyperalgesic effects [30]. Hecogenin also exhibits an antiinflammatory effect against gastric mucosal inflammation in rat induced by ethanol [31]. It is also used in pharmaceutical industry as a precursor for the synthesis of many steroidal hormone and steroidal anti-inflammatory drugs [32].

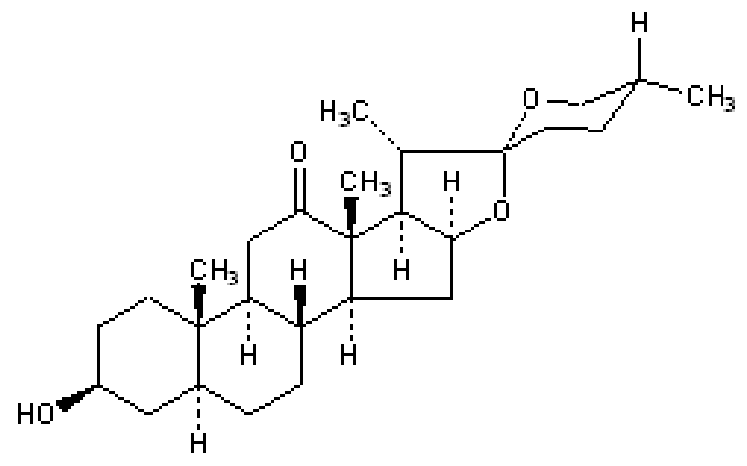

Fig. 2: Structure of hecogenin

\section{Anti-inflammatory role of hecogenin}

Inflammation is a multidimensional reaction of body tissues to harmful stimuli. It is a protective mechanism involving the activities of immune cells, molecular signals and vascular events. During the inflammation process, a wide range of inflammatory cytokines, chemical mediators and oxygen-derived free radicals are generated from the inflammatory and phagocytic cells that causes onset of inflammation reaction [33]. The treatment of inflammatory diseases involves the usage of non-steroid anti-inflammatory drugs (NSAID's) and other synthetic medications. The NSAID's and synthetic antiinflammatory drugs provide symptomatic relief and have numerous side effects. These drugs do not change the mechanism of inflammation, increases drug resistance and display inadequate target specificity. Hence, to overcome all these problems associated with synthetic anti-inflammatory drugs, it is needed to search a drug from natural source without or minimal side effects [33]. Ingawale and Patel, (2016) have explored the anti-inflammatory effect of hecogenin against croton oil induced ear edema in mice and cotton pellet induced granuloma in rat model. Result showed that, hecogenin significantly decreases the weight of inflamed ear of croton oil treated mice and percent inhibition of dry weight of granuloma tissue in cotton pellet induced granuloma model in rat was also found to be significantly decreased. Further, it also suppressed the myeloperoxidase and serum levels of Tumour necrosis factor- $\alpha$ (TNF- $\alpha$ ) and Interleukin- 6 (IL-6) in cotton pellets induced granuloma model in rat. The result was further supported by histopathological analysis of ear tissue that showed significant decrease in dermal thickness and epidermal hyperplasia of ear tissue thus confirming its anti-inflammatory activity [16] (fig. 3).

\section{Nociceptive role of hecogenin}

The pain sensation plays an imperative role as a protection and an alerting mechanism against the tissue damage. The endogenous pain inhibitory systems alter the pain sensations through the descending pain pathway system and release of neurotransmitter such as serotonin, noradrenalin, and endogenous opioids. The severity of pain sensation is reduced by the activation of descending pain pathway that lessens the transmission of nociceptive information [34]. Gama et al., (2013) have studied the anti-noceiceptive effect of hecogenin in tail flick and rota rod test in mice. In this study, the nociceptive threshold was evaluated by tail flick test and motor performance by rota rod test in mice. The intraperitoneal (i. p.) administration of hecogenin acetate $(5-40 \mathrm{mg} / \mathrm{kg})$ increased the tail flick latency time in a dose-dependent manner whereas; the systemic administration of hecogenin acetate 
(5-40 mg/kg) increased the Fos positive cells concentration in the gray mater. The data was further supported by immuno-histochemical detection of Fos protein expression in the gray mater. In addition to that, hecogenin acetate has promoted neuronal activation in the gray mater (main site of descending pain-inhibitory pathways) [35]. These data have confirmed that hecogenin acetate produces anti-nociceptive effect through the activation of opioid receptors and by endogenous analgesic mechanisms [28]. The anti-hyperalgesic activity of hecogenin acetate was tested in inflammatory models of mice with measurement of cytokine levels and c-fos expression on spinal cord area. The pre- treatment of mice with hecogenin acetate $(5,10$, or $20 \mathrm{mg} / \mathrm{kg}$; i. p.) inhibited the progress of mechanical hyperalgesia induced by TNF- $\alpha$, carrageenan, dopamine and prostaglandins $\mathrm{E}_{2}$. Furthermore, the immunofluorescence data confirmed that pre-treatment of mice with hecogenin acetate, significantly inhibited Fos expressions in the dorsal horn of spinal cord after carrageenan induced inflammation. The present results suggest that hecogenin acetate attenuates mechanical hyperalgesia by blocking c-fos expression in the spinal cord and by reduction of pro-inflammatory cytokines, such as interleukin-1 $\beta$ (IL1ß) [30] (fig. 4).

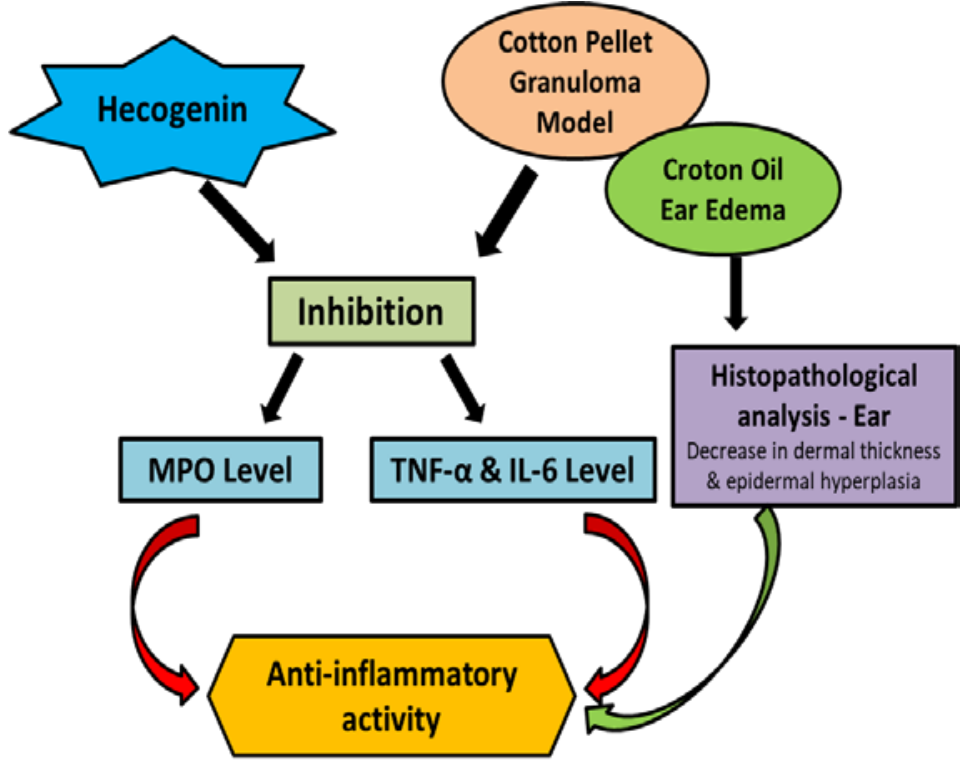

Fig. 3: Anti-inflammatory role of Hecogenin

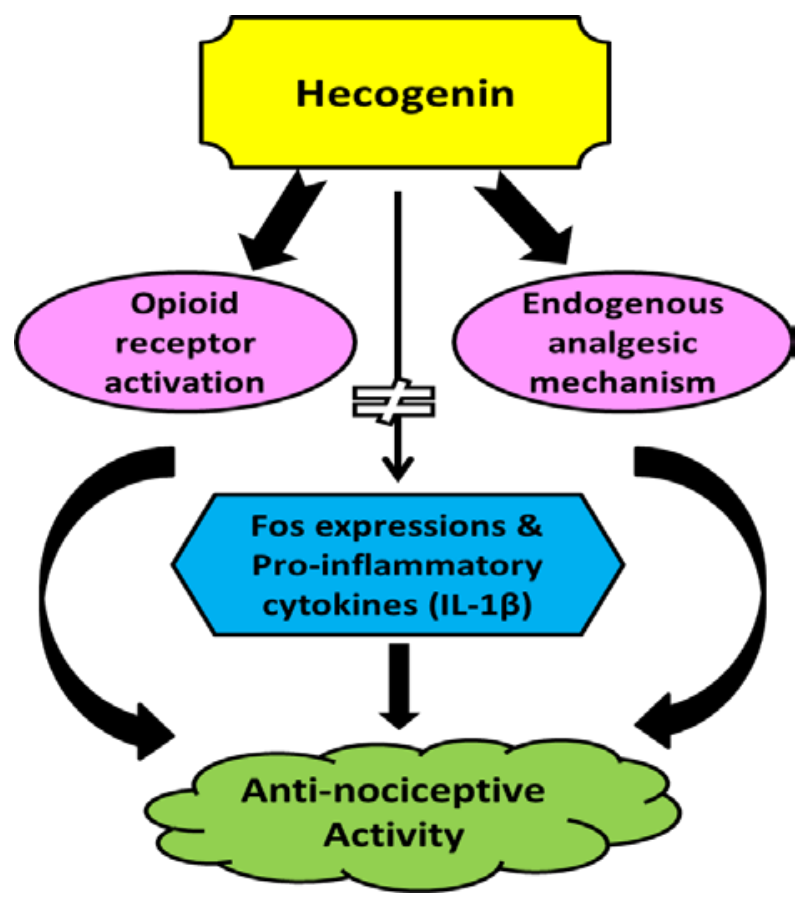

Fig. 4: Nociceptive role of Hecogenin

\section{Larvicidal role of hecogenin}

Dengue is a viral disease caused by the dengue virus, belonging to the family Flaviviridae. Dengue is communicated by several mosquito species of the genus Aedes, mainly Aedes aegypti. The control of dengue is depends on the mosquito combat, through the use of chemical insecticides. Oliveira et al., (2014), have examined the larvicidal activity of hecogenin acetate against Aedes aegypti 
larvae. Experimental result indicated that the hecogenin acetate does not killed larvaes in the first 24 and $48 \mathrm{~h}$, killed $10 \%$ of larvaes after $72 \mathrm{~h}, 80 \%$ of larvaes after $96 \mathrm{~h}$ and $95 \%$ of larvaes in $120 \mathrm{~h}$ in the concentration. The probable mechanism of larvicidal activity of hecogenin acetate was mimicking the insect growth hormone, preventing its development and death of virus [36] (fig. 5).

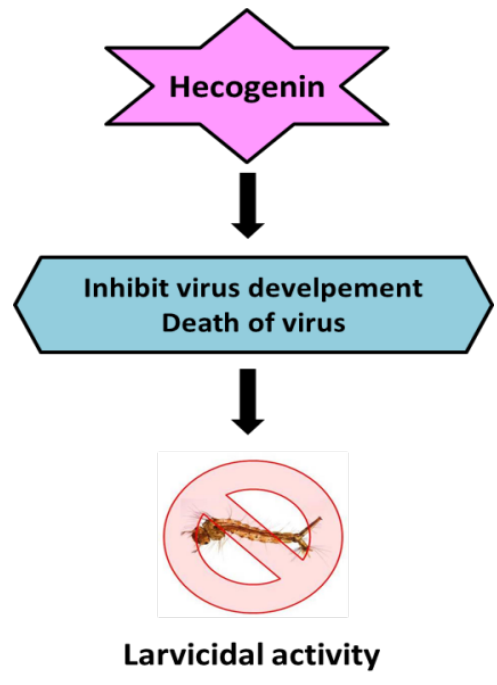

Fig. 5: Larvicidal role of hecogenin

\section{Gastroprotective role of hecogenin}

Gastric ulcer is a lesion on the mucosal epithelium of the stomach on exposure to excessive acid and destructive pepsin [37]. Gastric ulceration is the very common gastrointestinal disorder, accounting for 15 mortality cases out of every 15,000 complications in the world per year [38]. The treatment of gastric ulcer involves the usage of various techniques and medications such as vagotomy, prostaglandin analogs, $\mathrm{H}_{2}$ receptor antagonists and antacids to proton pump inhibitors. But, the above treatment is associated with gastrointestinal toxicity specifically due to NSAID's [39]. Currently available synthetic antiulcer drugs like ranitidine, cimetidine, misoprostol, omeprazole and esomeprazole are used for the management and treatment of NSAID induced gastric ulcer. But, these drugs are associated with simpler to severe side effects, provoking a search for non-toxic, affordable and easy availability of antiulcer medication [40, 41]. Exploration on the phytosteroids of medicinal plants that are widely used in the traditional systems of medicine might provide efficient remedy for the gastric ulcer treatment.

The gastroprotective activity of hecogenin was studied in ethanol and indomethacin induced gastric ulcer in mice. Hecogenin pretreatment in rats significantly reduced the gastric lesion in ethanol and indomethacin induced gastric ulcer in rats. The levels of lipid peroxidation and nitrite were found to be decreased with increased cyclooxygenase-2 (COX-2) expression. The gastroprotective effect of hecogenin was exhibited due to the synthesis of prostaglandin, opening of $\mathrm{K}^{+} \mathrm{ATP}$ channels and decreasing release of myeloperoxidase from neutrophils in vitro. These gastroprotective effects were confirmed by histological data of hecogenin in ethanol induced gastric ulcer in rats. The probable mechanism behind the gastroprotective activity would be antioxidant properties, generation of free radicals by increasing the glutathione level and the blockade of lipoperoxidation [14] (fig. 6).
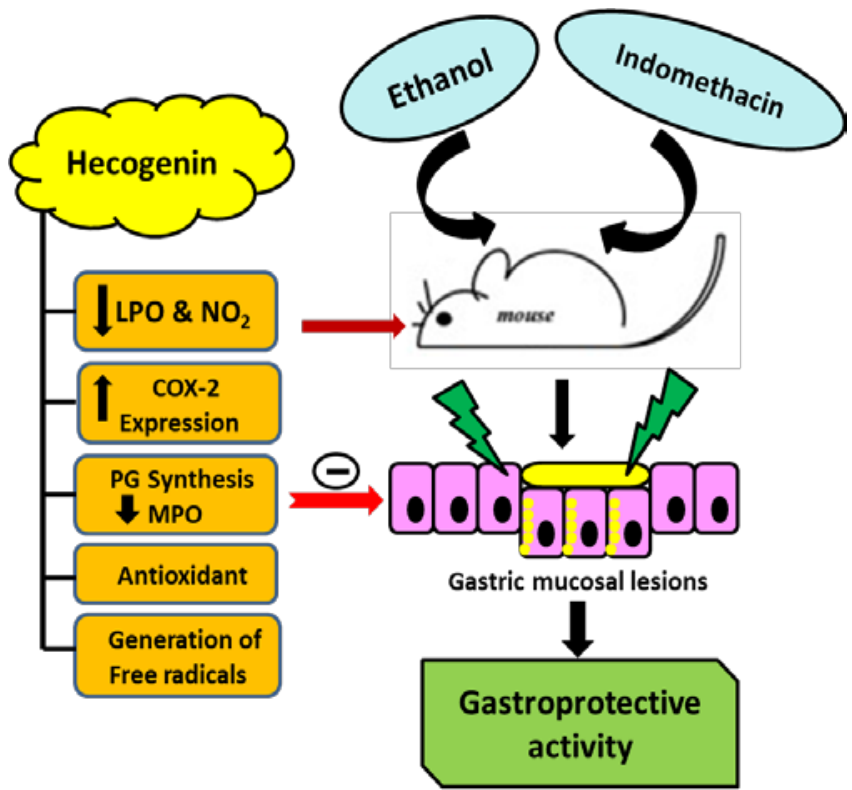

Fig. 6: Gastroprotective role of hecogenin 


\section{Anti-rheumatic role of hecogenin}

Rheumatoid arthritis is a systemic and chronic autoimmune joint disorder characterized by inflammation of the synovial membrane, hyperplasia, cartilage and functional disability of joints due to imbalance between pro-inflammatory and anti-inflammatory cytokines lead to auto-immunity sensitization and chronic inflammation $[42,43]$. Inflammatory mediators play an imperious role in the joint inflammation and damage process during the development of rheumatoid arthritis [44]. The drug treatment of rheumatoid arthritis have been transformed from conventional nonsteroidal anti-inflammatory drugs including aceclofenac, ibuprofen and naproxen with prednisone hormones and or disease-modifying anti-rheumatic drugs such as sulfasalazine, methotrexate and leflunomide to novel biological agents such as decoy TNF- $\alpha$ receptor and TNF- $\alpha$ antibody [45]. But, these treatments are allied to several side effects such as hematologic toxicity, gastrointestinal nephropathy, ulcerogenicity, cardiovascular complication and therefore, increase the cost of therapy [25]. Therefore, it is utmost emergency to develop a safer, new, efficient and economical agent for the treatment of rheumatoid arthritis.

Liagre et al., (2007) reported the anti-inflammatory effects of hecogenin in rheumatoid arthritis synovial cell survival. The results of study have shown that hecogenin inhibited the proliferation and induced apoptosis of human rheumatoid arthritis. The apoptosis induced by hecogenin was associated with overexpression of COX-2 enzyme activity correlated with the overproduction of endogenous prostaglandins $E_{2}$, activation of mitogen activated protein kinase, DNA fragmentation, activation of caspase- 3 and 9 a major markers of apoptosis [46]. Ingawale and Patel, 2018 have reported the antiarthritic activity of hecogenin through the suppression of proinflammatory cytokines in complete freund's adjuvant induced arthritis in rats. Results of the study have shown that hecogenin elicited significant reduction in the paw edema, arthritic score and joint diameter along with inhibition of joint destruction in histopathological and radiological analyzes of ankle joint. The biochemical level of serum transaminase serum phosphatase, myeloperoxidase level, haematological parameters such as haemoglobin, blood cells and inflammatory cytokines levels such as TNF- $\alpha$, IL-6, Interleukin-12 (IL-12) and Thromboxane $\mathrm{B}_{2}\left(\mathrm{TXB}_{2}\right)$ were found to be decreased after the treatment of hecogenin. The anti-arthiritc effect was supported by histopathological and COX-2 mRNA expression of rats. In histopathological analysis, the ankle joint treated with hecogenin showed pronounced inhibition of joint space narrowing, soft tissue swelling and bone erosion of ankle joint. The COX-2 expression of the hecogenin treated rats exhibited reduced levels of COX-2 mRNA enzymes indicating the anti-arthiritc activity of hecogenin [17] (fig. 7).

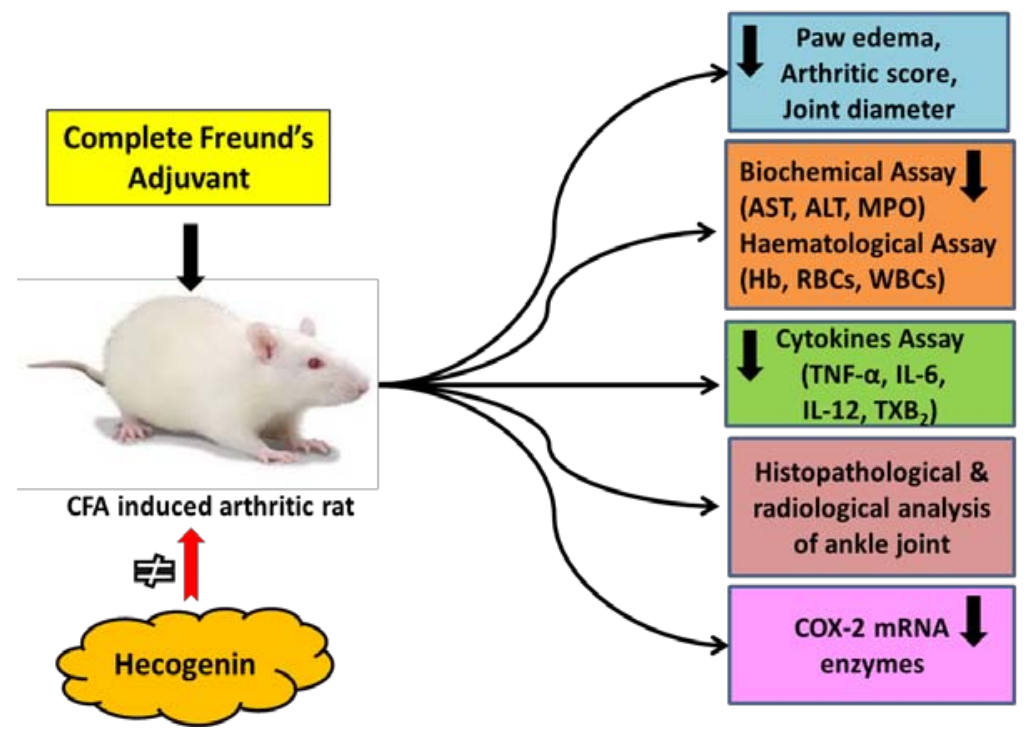

Fig. 7: Anti-rheumatic role of hecogenin

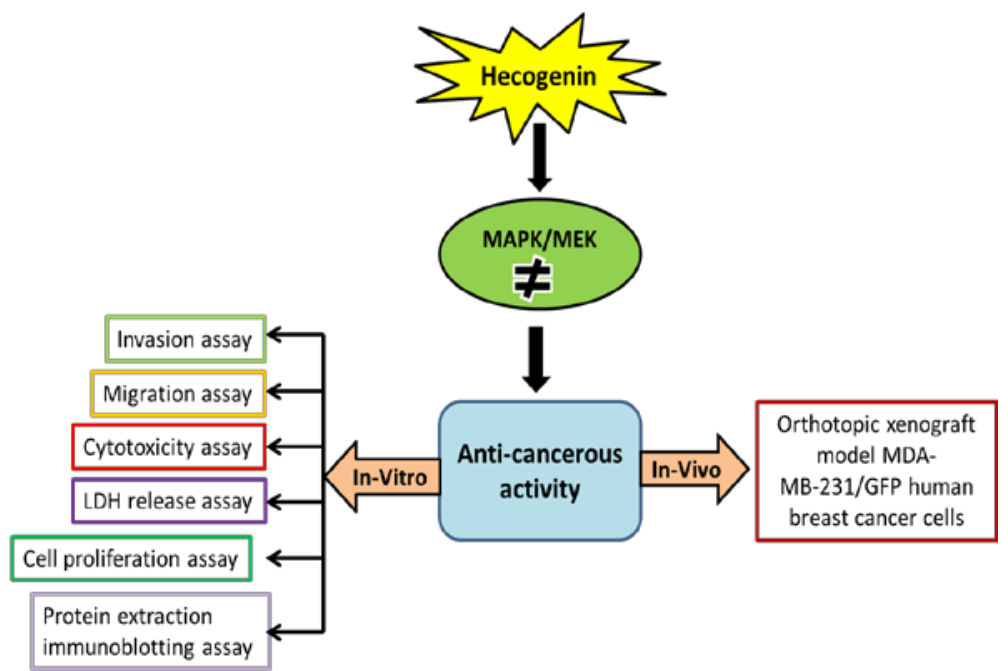

Fig. 8: Anti-cancerous role of hecogenin 


\section{Anti-cancer role of hecogenin}

Cancer is one of the world's most health concern and act as a primary medicinal chemistry and pharmacology targets. Breast cancer is the most common malignancy condition affecting the females worldwide. Breast cancer accounts for $25 \%$ of all the cancer cases and $15 \%$ of cancerous deaths among females [47]. Furthermore, breast cancer is considered as the leading cause of disability due to the deficiency of early diagnosis and effective treatments. Chemotherapy is the reputable forefront treatment for the treatment of cancer, but selectivity and off-target side effects are leading concerns. The treatment from cytotoxic chemotherapy has been surprising changed to successful molecular targeted cancer therapy, with significant safety [48].

Elsayed et al., (2017) have studied the anticancer effect of hecogenin thiosemicarbazone analogs as novel mitogen activated protein kinase/extracellular signal-regulated kinase (MEK) inhibitors for the control of breast cancer. In this study they have prepared thirty three analogs and tested on various in vitro (cell proliferation, cytotoxicity assay, lactate dehydrogenase release assay, migration assay, invasion assay, protein extraction and immunoblotting assay) and in vivo model (orthotopic xenograft model by using MDA-MB-231/GFP human breast cancer cells), among which hecogenin 12-(30-methylphenyl thiosemicarbazone) have demonstrated the most potent antiproliferative, anti-migratory and anti-invasive activities at low concentration level [18]. Cruz et al., (2016) have reported that cytotoxic, genotoxic and mutagenic effects of hecogenin on HepG2 cells. Hecogenin cytotoxicity was studied by performing MTT assay. Genotoxic and mutagenic potentials of hecogenin were assessed by comet assay and cytokinesis-block micronucleus assay. The result revealed that cell treated with hecogenin, no cytotoxic effect was observed on HepG2 cells in $10 \mu \mathrm{m}$ and $50 \mu \mathrm{m}$ concentrations range. Furthermore, exposure of cells to $100 \mu \mathrm{m}$ of hecogenin demonstrated a slight reduction in cell viability, whereas treatments with concentration above than $100 \mu \mathrm{m}$, cell viability decreased significantly by $30 \%$ [49] (fig. 8).

\section{CONCLUSION}

The current review article emphasized on the phytochemistry of saponins and sapogenins especially hecogenin isolated from Agave plants and their pharmacological roles. Hecogenin (steroidal saponin) found in a number of agave species is reported to have variety of multidimensional biological and therapeutic effects including antiinflammatory, anti-cancer, anti-rheumatic, gastroprotective, larvicidal, nociceptive activities. Because of this reason, hecogenin is a main biomolecule of interests in the prevention or treatment of numerous illnesses. The protective effects of hecogenin are due to multiple mechanisms including suppression of myeloperoxidase levels and serum levels of TNF- $\alpha$ and IL-6 in inflammation model, antinociceptive effect through the activation of opioid receptors and blocking c-FOS expression in the spinal cord and reducing the level of pro-inflammatory cytokines such as IL-1 $\beta$, gastroprotective effect due to antioxidant properties, generation of free radicals by increasing the glutathione level and the blockade of lipid peroxidation, anti-arthritic effect due to reduced levels of COX-2 mRNA enzymes and serum proinflammatory cytokines such as TNF- $\alpha$, IL-6, IL-12 and TXB 2 . From these collected information we can conclude that hecogenin has various exciting pharmacological potential such as anti-inflammatory, anti-nociceptive, antimicrobial, gastroprotective, anti-rheumatic, anticancer and larvicidal aspects.

\section{ACKNOWLEDGMENT}

The authors want to acknowledge Poona college of Pharmacy, Pune for online article support.

\section{FUNDING}

Nil

\section{AUTHOR CONTRIBUTION}

All the have been carried out by me.

\section{CONFLICTS OF INTERESTS}

The author has no conflicts of interest to declare.

\section{REFERENCES}

1. Hackman DA, Giese N, Markowitz JS, McLean A, Ottariano SG, Tonelli $\mathrm{C}$, et al. Agave (Agave americana): an evidence-based systematic review by the natural standard research collaboration. J Herb Pharmacother 2006;6:101-22.

2. Nava Cruz NY, Medina Morales MA, Martinez JL, Rodriguez R, Aguilar CN. Agave biotechnology: an overview. Crit Rev Biotechnol 2015;35:546-9.

3. Mellado Mojica E, Lopez MG. Identification, classification, and discrimination of agave syrups from natural sweeteners by infrared spectroscopy and HPAEC-PAD. Food Chem 2015;167:349-57.

4. Jones HD, Furbeck GN, Colorado R. Isolation and study of the saponin content of the juice and leaf of the agave plant, Maguey, Manso fino. J Am Pharm Assoc 1932;21:787-93.

5. Marker RE, Wagner RB, Ulshafer PR, Wittbecker EL, Goldsmith DPJ, Ruof CH. Steroidal sapogenins. J Am Chem Soc 1947;69:2167-230.

6. Simmons Boyce J, Tinto WF. Steriodal saponins and sapogenins from the Agavaceae family. Nat Prod Commun 2007;2:99-114.

7. Santos Zea L, Maria Leal Diaz A, Cortes Ceballos E, Gutierrez Uribe JA. Agave (Agave spp.) and its traditional products as a source of bioactive compounds. Curr Bioact Compd 2012;8:218-31.

8. Guclu Ustundag 0, Mazza G. Saponins: properties, applications and processing. Crit Rev Food Sci Nutr 2007;47:231-58.

9. Thakur M, Melzig MF, Fuchs H, Weng A. Chemistry and pharmacology of saponins: special focus on cytotoxic properties. Bot: Targets Ther 2011;1:19-29.

10. Elekofehinti 00. Saponins: anti-diabetic principles from medicinal plants: a review. Pathophysiol 2015;22:95-103.

11. Jiang S, Fan J, Wang Q, Ju D, Feng M, Li J, et al. Diosgenin induces ROS dependent autophagy and cytotoxicity via mTOR signaling pathway in chronicmyeloid leukemia cells. Phytomedicine 2016;23:243-52.

12. Huang B, Du D, Zhang R, Wu X, Xing Z, He Y, et al. Synthesis, characterization and biological studies of diosgenyl analogues. Bioorganic Med Chem Lett 2012;22:7330-4.

13. Chen Y, Tang YM, Yu SL, Han YW, Kou JP, Liu BL, et al. Advances in the pharmacological activities and mechanisms of diosgenin. Chin J Nat Med 2015;13:578-87.

14. Cerqueira GS, Silva GDS, Vasconcelos ER, Fragoso de FAP, Arcanjo MB, Silveira MD, et al. Effects of hecogenin and its possible mechanism of action on experimental models of gastric ulcer in mice. locamrahP J ruE 2012;683:260-9.

15. de Oliveira Rocha HA, Souza do Amaral V. Effect of hecogenin on DNA instability. Toxicol Rep 2016;3:539-43.

16. Ingawale DK, Patel SS. Anti-inflammatory potential of hecogenin in experimental animals: possible involvement of inflammatory cytokines and myeloperoxidase. Drug Res 2016;66:644-56.

17. Ingawale DK, Patel SS. Hecogenin exhibits anti-arthritic activity in rats through suppression of pro-inflammatory cytokines in complete freund's adjuvant induced arthritis. Immunopharmacol Immunotoxicol 2018;401:59-71.

18. Elsayed HE, Ebrahim HY, Haggag EG, Kamal AM, El Sayed KA. Rationally designed hecogenin thiosemicarbazone analogs as novel MEK inhibitors for the control of breast malignancies. Bioorganic Med Chem 2017;25:6297-312.

19. Hernandez Valle E, Herrera Ruiz M, Salgado GR, Zamilpa A, Ocampo ML, Aparicio AJ, Tortoriello J, et al. Anti-inflammatory effect of 3-0-[(6'-O-Palmitoyl)- $\beta$-d-glucopyranosyl Sitosterol] from Agave angustifolia on ear edema in mice. Molecules 2014;19:15624-37.

20. Ahumada Santos YP, Montes Avila J, de Jesus Uribe Beltran M, Diaz Camacho SP, Lopez Angulo G, Vega Avina R, et al. Chemical characterization, antioxidant and antibacterial activities of six Agave species from Sinaloa, Mexico. Ind Crop Prod 2013;49:143-9.

21. Morales Serna JA, Jimenez A, Estrada Reyes R, Marquez C, Cardenas J, Salmon M. Homoisoflavanones from Agave tequilana weber. Molecules 2010;15:3295-301. 
22. Almaraz Abarca N, Delgado Alvarado EA, Antonio Avila Reyes J, Uribe Soto JN, Gonzalez Valdez LS. The phenols of the genus Agave (Agavaceae). J Biomat Nanobiotechnol 2013;4:9-16.

23. Rizwan K, Zubair M, Rasool N, Riaz M, Zia-Ul-Haq M, de Feo V. Phytochemical and biological studies of Agave attenuata. Int J Mol Sci 2012;13:6440-51

24. Agrawal PK, Jain DC, Pathak AK. NMR spectroscopy of steroidal sapogenins and steroidal saponins: an update. Magn Reson Chem 1995;33:923-53.

25. Paik SY, Kok KH, Beak SM, Paek SH, Kim JA. The essential oils from Zanthoxylum schinifolium pericarp induce apoptosis of HepG2 human hepatoma cells through increased production of reactive oxygen species. Biol Pharm Bull 2005;28:802-7.

26. Eskander J, Lavaud C, Harakat D. Steroidal saponins from the leaves of Agave macroacantha. Fitoterapia 2010;81:371-4.

27. Santos J, Vieira I, Braz Filho R, Branco A. Chemicals from Agave sisalana biomass: isolation and identification. Int J Mol Sci 2015;16:8761-71.

28. Gama KB, Quintans JS, Antoniolli AR, Quintans Junior LJ, Santana WA, Branco A, et al. Evidence for the involvement of descending pain-inhibitory mechanisms in the antinociceptive effect of hecogenin acetate. J Nat Prod 2013;76:559-63.

29. Corbiere C, Liagre B, Bianch A, Bordji K, Dauça M, Netter P, Beneytout JL. Different contribution of apoptosis to the antiproliferative effects of diosgenin and other plant steroids, hecogenin and tigogenin, on human 1547 osteosarcoma cells. Int J Oncol 2003;22:899-905.

30. Quintans JSS, Barreto RSS, de Lucca W, Villarreal CF, Kaneto $\mathrm{CM}$, Soares MBP, et al. Evidence for the involvement of spinal cord-inhibitory and cytokines modulatory mechanisms in the anti-hyperalgesic effect of hecogenin acetate, a steroidal sapogenin-acetylated, in mice. Molecules 2014;19:8303-16.

31. Morikawa T, Li N, Nagatomo, A Matsuda H, Li X, Yoshikawa M. Triterpene saponins with gastroprotective effects from tea seed (the seeds of Camellia sinensis). J Nat Prod 2006;69:185-90.

32. Serafini LJ, Quintans MR, Antoniolli JSS, Viana dos Santos MR, Quintans Junior LJ. Mapeamento de tecnologias patenteaveis com o uso da hecogenina. Rev Geintec 2012;2:427-35.

33. Vinueza D, Lopez E, Acosta K, Abdo S. Assessment of antiinflammatory activity and cytotoxicity of freeze dried hydroalcoholic extract of bidens andicola on isolated neutrophils. Asian J Pharm Clin Res 2017;10:160-3.

34. Akanda MR, Park BY. Involvement of MAPK/NF-kappab signal transduction pathways: Camellia japonica mitigates inflammation and gastric ulcer. Biomed Pharmacother 2017;95:1139-46.
35. Yoshimura M, Furue H. Mechanisms for the anti-nociceptive actions of the descending noradrenergic and serotonergic systems in the spinal cord. J Pharmacol Sci 2006;101:107-17.

36. Oliveira L, Lacerda D, Nunes F. Effects of hecogenin on larvicidal activity against Aedes aegypti mosquito, the dengue vector. BMC Proc 2014;8:P33.

37. Khazaei M, Salehi H. Protective effect of Falcaria vulgaris extract on ethanol induced gastric ulcer in rat. Iranian J Pharmacol Ther 2006;5:1-4.

38. Sonnenberg A. Geographic and temporal variations in the occurrence of peptic ulcer disease. Scand J Gastroenterol Suppl 1996;110:11-24.

39. Shristi B, Neha J, Indu BP, Rajesh G. A review on some Indian medicinal plants for antiulcer activity. J Sci Res Pharm 2012;1:6-9.

40. Griffin MR, Scheiman JM. Prospects for changing the burden of nonsteroidal anti-inflammatory drug toxicity. Am J Med 2001;110:33S-7S

41. Akah PA, Orisakwe OE, Gamanies KS, Shittu A. Evaluation of nigerian traditional medicines: II. Effects of some Nigerian folk remedies on peptic ulcer. J Ethnopharmacol 1998;62:123-7.

42. Hawkins C, Hanks GW. The gastroduodenal toxicity of nonsteroidal anti-inflammatory drugs. A review of the literature. J Pain Symptom Manage 2000;202:140-51.

43. Smolen JS, Aletaha D, Koeller M, Weisman MH, Emery P. Emery, new therapies for treatment of rheumatoid arthritis. Lancet 2007;370:1861-74.

44. Nishat F, Syeda JF. Pharmacological screening for antiarthritic activity of Moringa oleifera. Asian J Pharm Clin Res 2016;9:106-11.

45. Tastekin N, Aydogdu N, Dokmeci D, Usta U, Birtane M, Erbas H et al. Protective effects of l-carnitine and alpha-lipoic acid in rats with adjuvant arthritis. Pharmacol Res 2007;56:303-10.

46. Liagre B, Vergne Salle P, Leger DY, Beneytout JL. Inhibition of human rheumatoid arthritis synovial cell survival by hecogenin and tigogenin is associated with increased apoptosis, p38 mitogen-activated protein kinase activity and upregulation of cyclooxygenase-2. Int J Mol Med 2007;20:451-60.

47. Saka S, Singh AN, Sharma N. Potential anti-cancer superfoods: a minireview. Int J Curr Pharm Res 2016;8:19-21

48. Torre LA, Bray F, Siegel RL, Ferlay J, Lortet Tieulent J, Jemal A. Global cancer statistics. CA Cancer J Clin 2012;652:87-108.

49. Cruz MS, Cabral Barroso S, Navoni JA, Rocha Silva Teles MM, Barbosa-Filho JM, de Oliveira Rocha HA, et al. Effect of hecogenin on DNA instability. Toxicol Rep 2016;3:539-43. 